\title{
Evaluation of SSR and important agronomical characters of promising mutant lines of soybean
}

\author{
ASADI, NURWITA DEWI, KRISTIANTO NUGROHO, RERENSTRADIKA TIZAR TERRYANA, MASTUR, \\ PUJI LESTARI ${ }^{\vee}$ \\ Indonesian Center for Agricultural Biotechnology and Genetic Resources Research and Development. Jl. Tentara Pelajar 3A, Bogor 16111, West Java, \\ Indonesia. Tel.: +62-251-8337975, Fax.: +62-251-8338820, ^email: plestari129@yahoo.com
}

Manuscript received: 5 August 2019. Revision accepted: 28 December 2019.

\begin{abstract}
Asadi, Dewi N, Nugroho K, Terryana RT, Mastur, Lestari P. 2020. Evaluation of SSR and important agronomical characters of promising mutant lines of soybean. Biodiversitas 21: 299-310. Improved soybean (Glycine max (L.) Merr.) varieties resistant to major pest or disease, and in accordance with consumer preferences are important in breeding programs to raise their productivity. Identification of superior promising mutant lines of soybean before releasing them needs multiple environment trials complemented with molecular assay. This study aimed to assess morpho-agronomical and molecular characters using SSR markers of promising mutant lines of soybean (Glycine $\max (\mathrm{L}$.) Merr.). A total of 14 SSR markers were used to evaluate 20 mutant lines along with their parental lines and check varieties, and eight different locations were chosen to field evaluation of 11 selected lines induced by gammaray. Values of Polymorphism Information Content, allele number, and gene diversity index were high, indicating the great genetic diversity among these mutant lines, and far distant from their parental lines. Phylogenetic tree also supported the distinguishable among gamma ray-induced mutant lines compared to the parental lines. The significant interaction between promising line and environment showed their high adaptability and stable yield in various environments. Biosoy-8 (2.713 ton/ha) and Biosoy-11 (2.631 ton/ha) revealing the high yields lines supported with the molecular information could be potential to be released as new varieties and can direct their efficient utilization for field application or further improvement scheme.
\end{abstract}

Keywords: Biosoy, gamma-ray, Glycine max, simple sequence repeat

\section{INTRODUCTION}

Soybean (Glycine $\max (\mathrm{L}$.$) Merr.), the most popular$ edible legume crop in Indonesia, has increased a deficit in its consumption in 2016-2020 with an average of $36.95 \%$ per year. While the shortage of soybean supply in 2020 is projected at approximately 1.91 million tons (Ministry of Agriculture 2016). Ironically to meet its demand, 2.67 tons per year are imported (BPS 2019), therefore, improved soybean variety adaptive to resistant to major pest or disease, and in accordance with consumer preferences is needed to raise its productivity. Breeding procedures in soybean in Indonesia have been put in high effort by broadening plant genetic diversity through various methods including mutation (Soeranto 2011), followed by systematic selection (Asadi et al. 2004; Carsono 2008). Induced mutation which affects genotypic and phenotypic changes (Dhanavel et al. 2012), can rapidly create the variability of inherited traits in crops both quantitatively and qualitatively (Muduli and Misra 2007). This approach has been effectively utilized in developing new and valuable alternation in plant characteristics that have contributed to increase yield potential or disease resistance.

Induced mutation technique could improve one or more characters without changing the basic character of native varieties. Induced mutation through seed becomes the most effective breeding approaches in developing improved varieties according to the desired characters (Arefrad et al. 2012; Gobinath and Pavadai 2015). Gamma rays-induced mutation is an efficient tool to produce mutant in crop breeding and at least 3212 mutants species obtained as direct mutants or derived from their crosses have been released worldwide (Kumar et al. 2014). Hereditary changes in various crops by using gamma irradiation have been reported (Ahloowalia et al. 2004), including in several legume crops such as cowpea (Girija et al. 2013), faba bean (Mejri et al. 2014), mungbean (Sangsiri et al. 2005) and soybean (Hanafiah et al. 2010; Pavadai et al. 2010; Arefrad et al. 2012; Gobinath and Pavadai 2015). In Indonesia, gamma rays induction has been used in breeding (Widiarsih and Swimahyani 2013), to broaden genetic diversity of plant species (Togatorop et al. 2016; Warid et al. 2017) and plant nutrition (Meliala et al. 2016). This approach has not only contributed to increase national agricultural production in Indonesia but also has generated hundred of promising mutant lines.

Multi-location trial, as the last step of phenotypic evaluation of plant varieties to be released, is needed to select superior and stable promising mutant lines and to understand the effect of genotype and environment. Notably, the significant interaction between promising mutant lines and environments would be valuable to indicate the superior varieties selected (Atta et al. 2009). A mutant line can be stable due to its high adaptability in various environments and irradiation-induced mutations combined with crossing governed the heredity of quantitative characters for new genotypes (Borevitz et al. 2003). Indonesian Center for Agricultural Biotechnology 
and Genetic Resources Research and Development (ICABIOGRAD) under the Indonesian Agency for Agricultural Research and Development (IAARD) has improved lines through hybridization and induced mutation applied in seeds and calli of soybean that need further evaluation. This study aimed to assess morphoagronomical characters and SSR of the promising soybean mutant lines to facilitate breeder in selection of superior lines with their characterized genetic variations.

\section{MATERIALS AND METHODS}

\section{Plant materials}

A total of 25 soybean genotypes were used in this study for field evaluation and SSR analysis. Selected 11 mutant lines (Biosoy-1 to Biosoy-11) of F8 generation derived from a cross of the soybean genotype from China (BioedKc-sm-4 reg. 05003-04452) and an introduced genotype from Japan (Bioed-Jp-O7), M0 (called as Biosoy), one of the parent from China (Bioed-Kc-sm-4 reg. 05003-04452) and two popular varieties with high yielding which have been released in 2008 and 2001, respectively (Grobogan and Anjasmoro) as check varieties were used for multiple environments assay. The 11 mutant lines were selected from a number of field evaluations of F8 population. However due to very limited seed, the genotype from Japan was not included in this assay but according to field valuation, one parent is sufficient as a control. In addition to the 11 mutant lines, nine more soybean mutant lines were evaluated their molecular characters using SSR markers. The list of soybean mutant lines along with the parental lines and check varieties which were denoted as M1-M25 is presented in Table 1.

\section{Mutation breeding scheme}

Two introduced soybean varieties, China (Bioed-Kcsm-4 reg. 05003-04452) and Japan (Bioed-Jp-O7) were crossed to produce F1 population in 2008. The lines of F2F5 generations were then selected in field evaluation in experimental field station, Pacet, West Java (928 m above sea level). Modified bulk selected plants showing at least two good agronomic characters (such as large seeds and high number of pods) in each generation were mixed and subsequently planted to produce seeds of next generation. In the F5 population, individual plant was selected according to the pedigree which was performed up to the 7th generation (F7). In 2014, one of the homozygous F8 lines having large seeds, high number of pods and numerous branches (KC/KJ-F8-1 line) was obtained and selected for further physical mutation with gamma-ray. The gamma-ray irradiation has been done in the National Nuclear Energy Agency of Indonesia with doses of 200 and 250 gray. The gamma irradiation was expectedly to produce mutants with high yield potential, large seed size of about $20 \mathrm{~g} / 100$ seeds, and early to moderate maturity. The pedigree and selection of mutant lines are presented in Figure 1.

\section{DNA isolation}

Genomic DNA was isolated from young and fresh leaves of one-month-old soybean plant. The fully expanded first trifoliate leaf was fully grounded in liquid nitrogen to a fine powder using pestle and mortar. The DNA was extracted using cetyl trimethyl ammonium bromide (CTAB) method according to the protocol of Doyle and Doyle (1990). The quantity and purity of genomic DNA were determined using agarose gel electrophoresis and NanoDrop 2000 spectrophotometer (Thermoscientific Co., USA).

\section{PCR amplification using SSR markers}

A total of 14 universal SSR markers used in this study was accessed from USDA-ARS Soybean Genome Database (http://129.186.26.94/SSR.html) (Table 2). DNA amplification using Polymerase Chain Reaction (PCR) was performed in a total volume of $10 \mu \mathrm{L}$ containing $20 \mathrm{ng}$ of template DNA, $10 \mu \mathrm{M}$ of each primer (forward and reverse), $5 \mu \mathrm{L}$ of KAPA PCR ready mix (KAPA Biosystem). The PCR amplification was programmed to initial denaturation at $94{ }^{\circ} \mathrm{C}$ for $5 \mathrm{~min}$, cycle 35 times under the following conditions: denaturation for $30 \mathrm{~s}$ at $94{ }^{\circ} \mathrm{C}$, annealing for $1 \mathrm{~min}$ at $55^{\circ} \mathrm{C}$, and elongation for $2 \mathrm{~min}$ at 72 ${ }^{\circ} \mathrm{C}$. Final extension was held for $5 \mathrm{~min}$ at $72{ }^{\circ} \mathrm{C}$. Amplicons were migrated on $8 \%$ non-denatured polyacrylamide gels and used a $100 \mathrm{bp}$-DNA ladder for molecular weight size. The electrophoresed gel was stained with ethidium bromide and visualized under ultraviolet light in UV Transilluminator (UVP, UK) and documented for allele detection.

Table 1. List of 25 soybean genotypes used in this study

\begin{tabular}{ll}
\hline Code & Line (genotype name) \\
\hline M1 & Ped M6-A1-28-2 \\
M2 & Ped M6-A1-31-3 (Biosoy-1) \\
M3 & Ped M6-A1-44-2 (Biosoy-2- \\
M4 & Ped M6-A1-488-1 (Biosoy-3) \\
M5 & Ped M6-A1-420-3 (Biosoy-4) \\
M6 & Ped M6-A1-487-1 (Biosoy-5) \\
M7 & Ped M6-A1-488-2 (Biosoy-6) \\
M8 & Ped M6-A2-267-3 \\
M9 & Ped M6-B2-896-1 (Biosoy-7) \\
M10 & Ped M6-B2-2109-1 (Biosoy-8) \\
M11 & Ped M6-B2-1243-2 \\
M12 & Ped M6-B2-1533-2 \\
M13 & Bulk-Ped M6-A-5-2 (Biosoy-9) \\
M14 & Bulk-Ped M6-A-5-18 \\
M15 & Bulk-Ped M6-A-33 (Biosoy-10) \\
M16 & Bulk-Ped M6-A-44 \\
M17 & Bulk-Ped M6-B-5-10 (Biosoy-11) \\
M18 & Bulk-Ped M6-A-5-17 \\
M19 & Bulk-Ped M6-A-B5-22 \\
M20 & Bulk-Ped M6-B-5-29 \\
M21 & Chinese genotype (Bioed-Kc-sm-4 reg. 05003-04452) \\
M22 & Grobogan \\
M23 & Parental line of Biosoy-M0 (M0-FC3) \\
M24 & Parental line of Biosoy-M0 (M0-FC4) \\
M25 & Anjasmoro \\
\hline
\end{tabular}




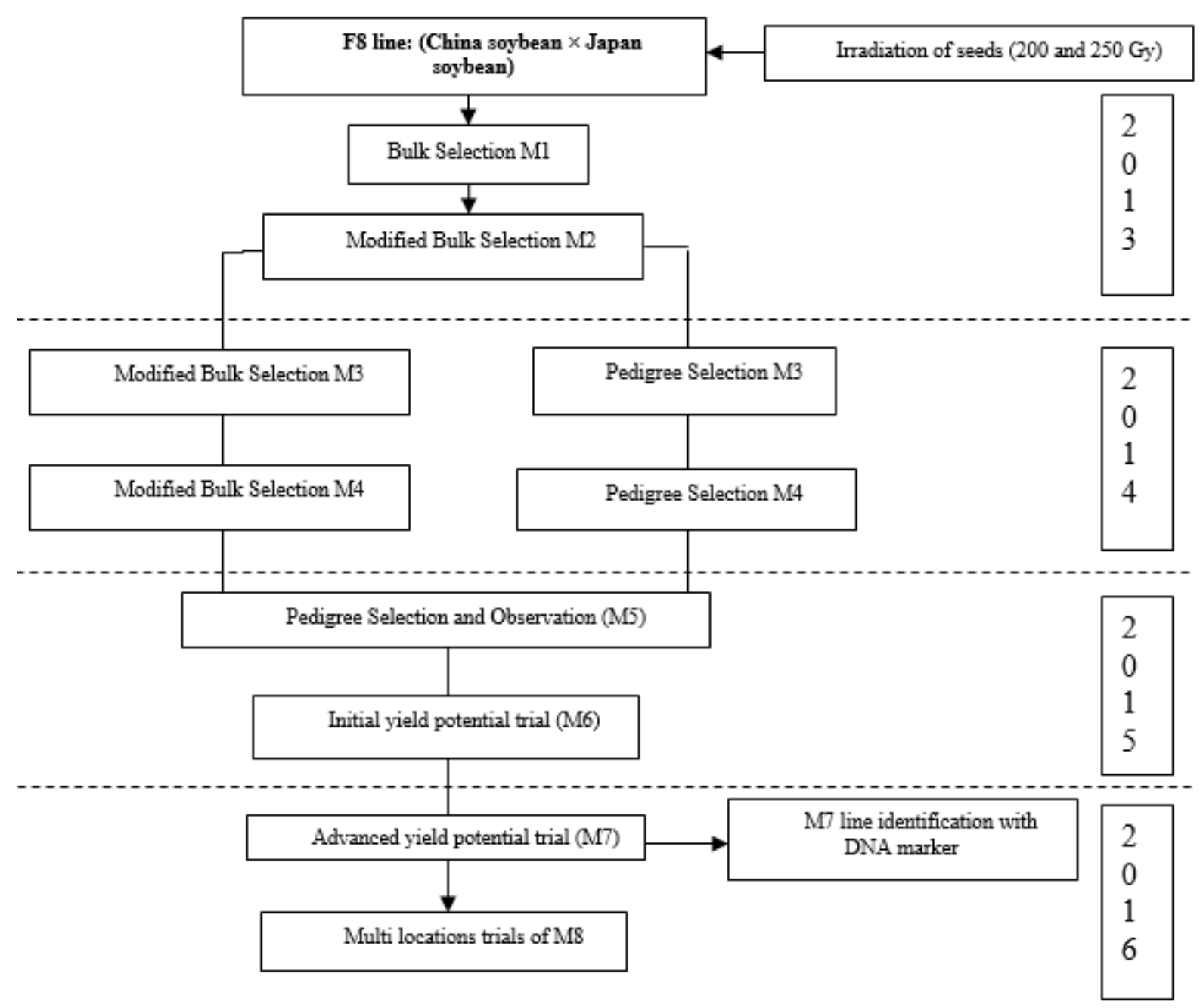

Figure 1. Genealogy and flow chart to produce soybean mutant lines

\section{Molecular data analysis}

The DNA bands were scored as binary data to all SSR loci. It was assumed that each band visualized in the polyacrylamide gel was one allele and considered the bands with the same movement pattern to have the same locus. A score of 1 (one) to the bands that were visualized, and a score of 0 (zero) to the bands that were not produced at the same sizing, whereas the samples that did not produce amplicons were given a score of 9 which is considered as missing data. The gel analyzer software facilitates to determine the position of the band. Genetic similarity between lines was estimated according to the formula of Nei and Li (1979). Statistical summary of polymorphism information content (PIC), allele number, heterozygosity, gene diversity index was calculated using PowerMarker V3.25 software (Liu and Muse 2005). Unweighted Pair Group Method with Arithmetic mean (UPGMA) cluster analysis was used to assess pattern of diversity among the mutant lines. Dendrogram was constructed with the TREE program of NTSYS-pc version 2.1 software (Rohlf 2000).
Field evaluation in multiple locations and data analysis

A total of 11 mutant lines with high yields and good agronomic performances were selected based on advanced yield trials in 2015, and subsequently evaluated in multiple environment trials in 2016. Field assays of 11 promising mutant lines (M2, M3, M4, M5, M6, M7, M9, M10, M13, M15, M17) and four varieties as control (M21, M22, M24, M25) (Table 1) were carried out in eight agro-ecosystems for study sites (Table 3). The eight environments in seven locations included in West Java (Cibatok, Kuningan, Pusakanagara, Muara on dry season and Muara on rainy season), specific location in Yogyakarta (Wonosari), East Java (Kendalpayak) and West Nusa Tenggara (West Lombok) were sufficient for releasing new varieties as recommended by Ministry of Agriculture. A thorough land preparation before planting was done in order for giving an optimum soybean plant population for the highest possible yield and weed control. Field for soybean cultivation is dryland farming which is was completely processed along with the soil treatment or additional manure (mature and dry) with a dose of 1 ton/ha. The standard evaluation followed recommended procedure in soybean cultivation. 
Table 2. SSR markers used to assess the molecular level of soybean mutant lines in the study

\begin{tabular}{|c|c|c|c|}
\hline $\begin{array}{c}\text { SSR } \\
\text { marker }\end{array}$ & Sequence & Motif of SSR & $\begin{array}{c}\text { Chromosome } \\
\text { number }\end{array}$ \\
\hline Satt002 & $\begin{array}{l}\text { F: TGTGGGTAAAATAGATAAAAAT } \\
\text { R: TCATTTTGAATCGTTGAA }\end{array}$ & (TA)5TGTACGATTTAAAAATAAAATA(AT)5 & Gm17 \\
\hline Satt030 & $\begin{array}{l}\text { F: AAAAAGTGAACCAAGCC } \\
\text { R: TCTTAAATCTTATGTTGATGC }\end{array}$ & (ATA) 21 & Gm13 \\
\hline Satt045 & $\begin{array}{l}\text { F: TGGTTTCTACTTTCTATAATTATTT } \\
\text { R: ATGCCTCTCCCTCCT }\end{array}$ & (ATT) 18 & Gm15 \\
\hline Satt063 & $\begin{array}{l}\text { F: AAATGATTAACAATGTTTATGAT } \\
\text { R: ACTTGCATCAGTTAATAACAA }\end{array}$ & $(\mathrm{TAA}) 20$ & Gm14 \\
\hline Satt197 & $\begin{array}{l}\text { F: CACTGCTTTTTCCCCTCTCT } \\
\text { R: AAGATACCCCCAACATTATTTGTAA }\end{array}$ & (ATT) 20 & Gm11 \\
\hline Satt 463 & $\begin{array}{l}\text { F: TTGGATCTCATATTCAAACTTTCAAG } \\
\text { R: CTGCAAATTTGATGCACATGTGTCTA }\end{array}$ & (ATT) $19(\mathrm{CAA})$ & Gm7 \\
\hline GmES1424 & $\begin{array}{l}\text { F: TCTTCGGTGTTGCAATCAAG } \\
\text { R: ACAACCTTCAAACTGGCTGG }\end{array}$ & (AG) 15 & Gm15 \\
\hline GmES1604 & $\begin{array}{l}\text { F: GTTGCAGGCACACTGGAGTA } \\
\text { R: CTCAGCCTTCTTCCCTGTTG }\end{array}$ & (AAG) 28 & Gm08 \\
\hline GmES1845 & $\begin{array}{l}\text { F: CAGGAAGCACATAACCACTTCA } \\
\text { R: CCCGGTAGCATAACTTCATCA }\end{array}$ & (AAG) 24 & Gm01 \\
\hline GmES2225 & $\begin{array}{l}\text { F: CCTCCTAATGAGGCCAATGA } \\
\text { R: ATTATTCCGGCCAAACTTCC }\end{array}$ & (AAT) 15 & Gm13 \\
\hline GmES3515 & $\begin{array}{l}\text { F: TGCGGAAGAGATTGAGTGTG } \\
\text { R: ATGGTGTGCAAGAACCTTCC }\end{array}$ & (ATC) 18 & Gm13 \\
\hline GAT19 & $\begin{array}{l}\text { F: TGTATCATTCACACAAACAA } \\
\text { R: GACAAAGGTAATAAAATCGTAG }\end{array}$ & (AT) 30 & Gm8 \\
\hline GATT43 & $\begin{array}{l}\text { F: AAAATCGTATTCTTCTTCCCA } \\
\text { R: GATTGGGTAATTGTTGGAGAAA }\end{array}$ & (ATT) 19 & Gm3 \\
\hline GAAT47 & $\begin{array}{l}\text { F: TGTCCATGTTTAGTGATGAGGC } \\
\text { R: CTGTTGTGATCGGAAGGTGTAG }\end{array}$ & (AAT) 16 & Gm6 \\
\hline
\end{tabular}

Table 3. Characteristics of locations used to evaluate promising soybean mutant lines in 2016

\begin{tabular}{lcl}
\hline \multicolumn{1}{c}{ Location } & $\begin{array}{c}\text { Altitude } \\
\text { (m asl.) }\end{array}$ & Soil type \\
\hline Cibatok, West Java & 250 & Latosol \\
Kuningan, West Java & $572-586$ & Latosol \\
Pusakanagara, West Java & $70-127$ & Gleisol Hidrik \\
Muara GS1, dan GS2, West Java & 250 & Latosol \\
Wonosari, Yogyakarta & $150-200$ & Grumosol \\
Kendalpayak, East Java & 400 & Entisol \\
West Lombok (West Nusa Tenggara) & & Inceptisol \\
\hline
\end{tabular}

The experiment was laid out in a randomized block design with 3 replications. A total of 11 promising mutant lines along with four check varieties were planted using 2.4 $\mathrm{m} \times 4.8 \mathrm{~m}$ plot size of each line, $40 \mathrm{~cm} \times 15 \mathrm{~cm}$ plant spacing, two grains per hill. Fertilizers of $50 \mathrm{~kg} / \mathrm{ha}$ urea, $250 \mathrm{~kg} / \mathrm{ha} \mathrm{SP} 36,100 \mathrm{~kg} / \mathrm{ha} \mathrm{KCl}$ and 1 ton/ha organic fertilizers were applied at the same time as sowing the grains along the rows of plants. Controlling of pests, diseases and weeds were carried out according to the recommended procedure on soybean cultivation. Irrigation was applied routinely to maintain optimum soil moisture. Agronomic traits (yield and component) were measured namely days to flowering (DF), days to maturity (DM), plant height $(\mathrm{PH})(\mathrm{cm})$, number of pods $(\mathrm{NP})$, number of fertile node (NFN), number of branches (NB), 100 seed weight (100 SW) (g), and seed yield (SY) (ton/ha). Days to flowering was determined when $50 \%$ of plants per plot have at least one flower (R1-R2 of growth stage), and days to maturity was estimated when $50 \%$ of plants per plot reached R7 (one normal pod on the main stem that has reached its mature pod color) or R8 (95\% of the pods which have reached their mature pod color) of soybean growth stage. Plant height, number of pods, number of fertile nodes, number of branches and 100 seed weight were estimated based on the mean of 10 individual plants as samples. Yield per line was calculated by weighing the harvested grains of all plant clumps in one plot then converted into $12 \%$ of water content to adjust at the same moisture of seeds. All collected data were subjected to be analyzed with a single-variant test.

Variance analysis (F test) was carried out partially in each location of field trial. If the $\mathrm{F}$ test has a significant effect then the middle value is further tested by Duncan's Multiple Range Test (DMRT) at 5\% significance level (Gomez and Gomez 1984). Statistical analysis was performed using the SAS program (SAS 2002). In particular, seed yield (12\% moisture content) per unit area was done using combined analysis of variance. If an interaction is demonstrated between the genotypes and environments (locations) as expected, further analysis of yield stability (Eberhart and Russell 1966) and adaptability (Finlay and Wilkinson 1963) would be estimated following the linear model as follows: 
$\ddot{Y} i j=\mu+\beta i \mathrm{Ij}+\delta \mathrm{ij}, \mathrm{i}=1,2,3, \ldots . \mathrm{g}$

Where,

Ÿij : the average yield of the $i$-th line at the $j$-th location.

$\mu \quad$ : average yield of all lines at all locations

$\beta \mathrm{i} \quad$ : regression coefficient that measures the response of the i-th line for results at different locations

$\mathrm{Ij} \quad$ : location index to $\mathrm{j}$

$\mathrm{I}$ as an environmental index is defined as:

Ij $\quad:\left(\sum \mathrm{i} Y \mathrm{ij} / \mathrm{g}\right)-\left(\sum \mathrm{I} \sum \mathrm{j} \mathrm{Yij} / \mathrm{gn}\right)$, and $\Sigma \mathrm{j} \mathrm{Ij}: 0$

$\delta \mathrm{ij}:$ Deviation from the $\mathrm{i}$-th line regression at the $\mathrm{j}$ location

The assessment criteria that a line is considered stable results in various locations (environment) if it has a regression coefficient not different from one and the regression deviation is not significantly different from 0 , and has a potential yield above the average.

Regression coefficient values are also used as assessors of adaptability:

$\beta \mathrm{i}<1.0$ : has stability above average, adapt specifically at marginal environments

$\beta \mathrm{i}=1.0$ : has average stability, adapt well at all environments

$\beta \mathrm{i}>1.0$ : has stability below average, adapt specifically at productive environments

\section{RESULTS AND DISCUSSION}

\section{Molecular diversity among soybean mutants}

Physical mutagenesis produces any DNA changes of point mutation, insertion, deletion that can affect phenotypic variation. Mutation breeding-derived crop varieties followed by selection provide appropriate genetic materials that could be beneficial for crop improvement (Oladose et al. 2015). Molecular markers with high mutation in genome such as simple sequence repeats (SSR) could be useful for characterization of promising soybean mutant lines in our study. Assessment of 25 soybean genotypes consisting of 20 gamma-ray induced-soybean mutant lines, the parental lines and check varieties (M1M25) as presented in Table 1 was attempted using 14 SSR markers to complement the phenotypic characters which are important in support of their efficient utilization.

All the SSR markers genotyped on 20 soybean mutant lines including the parental lines and check varieties were found to be highly polymorphic. The high number of alleles per locus and average number of allele was observed in this selected soybean mutant line. An average of 16.57 alleles with a range of 9-28 alleles per locus was identified. The lowest major allele frequency was estimated to be $10 \%$ (Satt30) and the highest one was $40 \%$ (GmES1424). The average gene diversity index was considerably high (0.90) (Table 4), indicating its relevance to previous reports that used similar universal SSR markers and displayed moderate to high variability in mutants (Tembo and Munyinda 2015; Yuliasti and Reflinur 2017). In addition, this study was in good agreement with previous report from Herrera et al. (2008), that gene diversity of each SSR locus was correlated with the number of alleles and number of repeat motifs. Heterozygosity was also identified in a number of SSR loci in these mutants, suggesting the segregated soybean mutant lines observed in this study. Unique alleles existed in lines of M5, and M15 on specific loci, allowing to determine DNA fingerprint for its genetic identity (Choudhary et al. 2011; Lestari et al. 2016). The PIC (Polymorphism Information Content) reflecting the polymorphism and allele frequency among lines, were not uniform and ranged from 0.77 (GmES1424) to 0.96 (Satt197) with an average of 0.90. Our study demonstrated that 13 out of the 14 markers revealed a high PIC value (PIC > 0.8), which suggest their effectiveness for further use of genetic studies of soybean mutant (Malek et al. 2014). Importantly, this high gene diversity could provide a good basis for DNA profiling of soybean mutant (Tsuda et al. 2015). An example of amplicons generated by the SSR marker of Satt 002 and Satt 030 is shown in Figure 2.

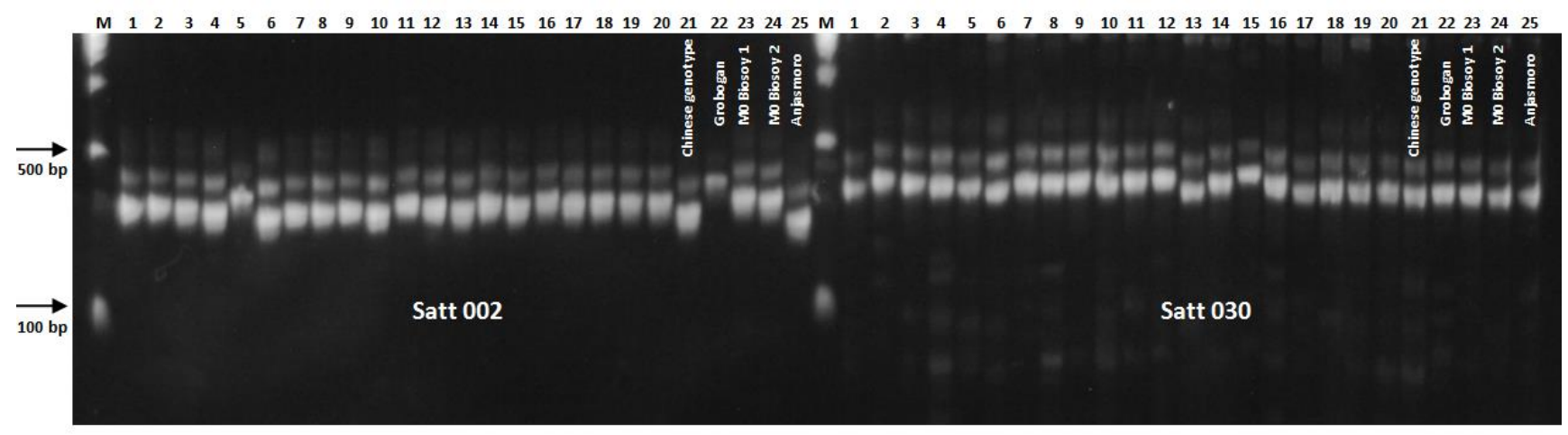

Figure 2. Example of banding pattern of soybean mutant lines in comparison with their parental line and check varieties based on SSR markers migrated in $8 \%$ polyacrylamide gel. Note: well number. 1-20: mutant lines; 21, 22, 25: check varieties; 23-24: parental lines of M0 Biosoy as listed in Table 1 
Table 4. Summary statistics of SSR polymorphism observed on 20 soybean mutant line compared to their parental lines and check varieties

\begin{tabular}{lccccc}
\hline \multicolumn{1}{c}{ Primer } & Allele number & $\begin{array}{c}\text { Major allele } \\
\text { frequency }\end{array}$ & $\begin{array}{c}\text { Gene diversity } \\
\text { index }\end{array}$ & PIC & Heterozygosity \\
\hline Satt002 & 20 & 0.14 & 0.93 & 0.93 & 0.92 \\
Satt030 & 22 & 0.10 & 0.94 & 0.94 & 1.00 \\
Satt045 & 18 & 0.16 & 0.91 & 0.91 & 0.88 \\
Satt063 & 20 & 0.16 & 0.90 & 0.90 & 0.80 \\
Satt197 & 28 & 0.08 & 0.96 & 0.96 & 0.84 \\
Satt 463 & 10 & 0.22 & 0.87 & 0.85 & 0.76 \\
GmES1424 & 9 & 0.40 & 0.79 & 0.77 & 0.00 \\
GmES1604 & 14 & 0.16 & 0.91 & 0.91 & 0.00 \\
GmES1845 & 12 & 0.16 & 0.89 & 0.88 & 0.00 \\
GmES2225 & 12 & 0.20 & 0.89 & 0.88 & 0.00 \\
GmES3515 & 16 & 0.15 & 0.91 & 0.90 & 0.21 \\
GAT19 & 17 & 0.18 & 0.90 & 0.89 & 1.00 \\
GATT43 & 13 & 0.12 & 0.91 & 0.91 & 0.00 \\
GAAT47 & 21 & 0.13 & 0.93 & 0.93 & 1.00 \\
Mean & 16.57 & 0.17 & 0.90 & 0.90 & 0.53 \\
-
\end{tabular}

Note: PIC: polymorphism information content

Phenogram was generated from the SSR banding pattern demonstrated that gamma-ray induced mutation produced new alleles as proved by mutant lines which felt 25 genotypes into two distinctive clusters (Figure 3) between mutants and their parental lines along with check varieties. This result is in good agreement with previous studies showing different clustering of other bean mutants and their parental genotypes (Tembo and Munyinda 2015). The first cluster consisted of 20 mutant lines with two subclusters, in particular, M6 (Biosoy-6) was solely in the second sub-cluster, indicating its far distance from the other mutant lines due to genetic change as observed by this SSR. Even though this SSR is universal markers, the distinctive of Biosoy-6 was relevant with agronomic and yield characters that differed from other mutant lines (Table 7). The two parental lines from China (M23 and M24), derived crosses of Chinese genotype and Japanese genotype demonstrated its far distant as a result of mutation. The maximum similarity was demonstrated by M2 with M7, and M8 with M9, accounting for $87.3 \%$. This was slightly greater than the closest mutant line (M20) with the parent (M24) which had similarity of $83.8 \%$, as a result of gamma-ray mutation which affected genotypic and phenotypic changes. In contrast, minimum similarity was observed on mutant lines of M4, M6, M7, and M12 with their parent (M24). Notable, all mutant lines were genetically differentiated from their parents, and it reflected morpho-agronomical characters' changes. Such variation by mutation in our study, a desirable tool like in most selfpollinated crops, is important for soybean breeding (Acquaah 2007) that could generate superior lines.

To observe gamma-ray induction that produces insertions/deletions (indels), SSR motif on parent of Biosoy-M0 was identified in certain loci. Majority motifs of trimer (such as AAG, CTT, GAT, ATA, ATT, TTA) and minor one of dimer (TC) with varied repeats were found. The maximum length of SSR repeat was observed as $\mathrm{ATT}_{21}$ by Satt002, while the lowest repeat number $\left(\mathrm{CTT}_{4}\right)$ was produced by GMES1845. Thus, according to allele size differences, indels could effectively be identified among mutant lines compared to the parent. Similarly to previous studies (Lenis et al. 2010; Hamzekhanlu et al. 2011), most of the mutant lines were able to be differentiated each other using a single marker or combination markers. Our study confirmed a high potential of SSR markers as robust molecular markers for soybean promising mutant lines differentiation, and evaluation of their genetic variation. Such DNA profiling is usable in soybean genetic identification, selection of progenies to support breeding and protection to complement quantitative traits (Sonia et al. 2012).

The varied soybean mutant lines that able to produce promising lines in this study is in good agreement with previous reports which resulted that a specific dose of gamma-ray induction could cause in genetic changes and influence the variability of plant growth and development of soybean mutants either via qualitative or quantitative morphological characters that ultimately could affect the plant yield (Karthika and Lakshmi 2006; Hanafiah et al. 2010; Malek et al. 2014). Induced gamma ray-potential high yielding soybean mutant with significantly increased grain and yield components reflected their molecular level distinctness (Mudibu et al. 2012). In this study, SSR marker demonstrated the robustness to identify the variation of mutant lines having different agronomical characters from the parental lines and could be further evaluated in genetic level as demonstrated by Lee et al. (2014) that DNA-based sequencing could be useful for elucidating the lipoxygenase content to develop soybean cultivars with improved flavor. Even though there has been limited report on induced gamma-ray in soybean, this study proved that combination between gamma-ray mutation and crossing is an effective tool to broaden genetic variation of soybean as well as to develop new soybean varieties with increased yield potential. 


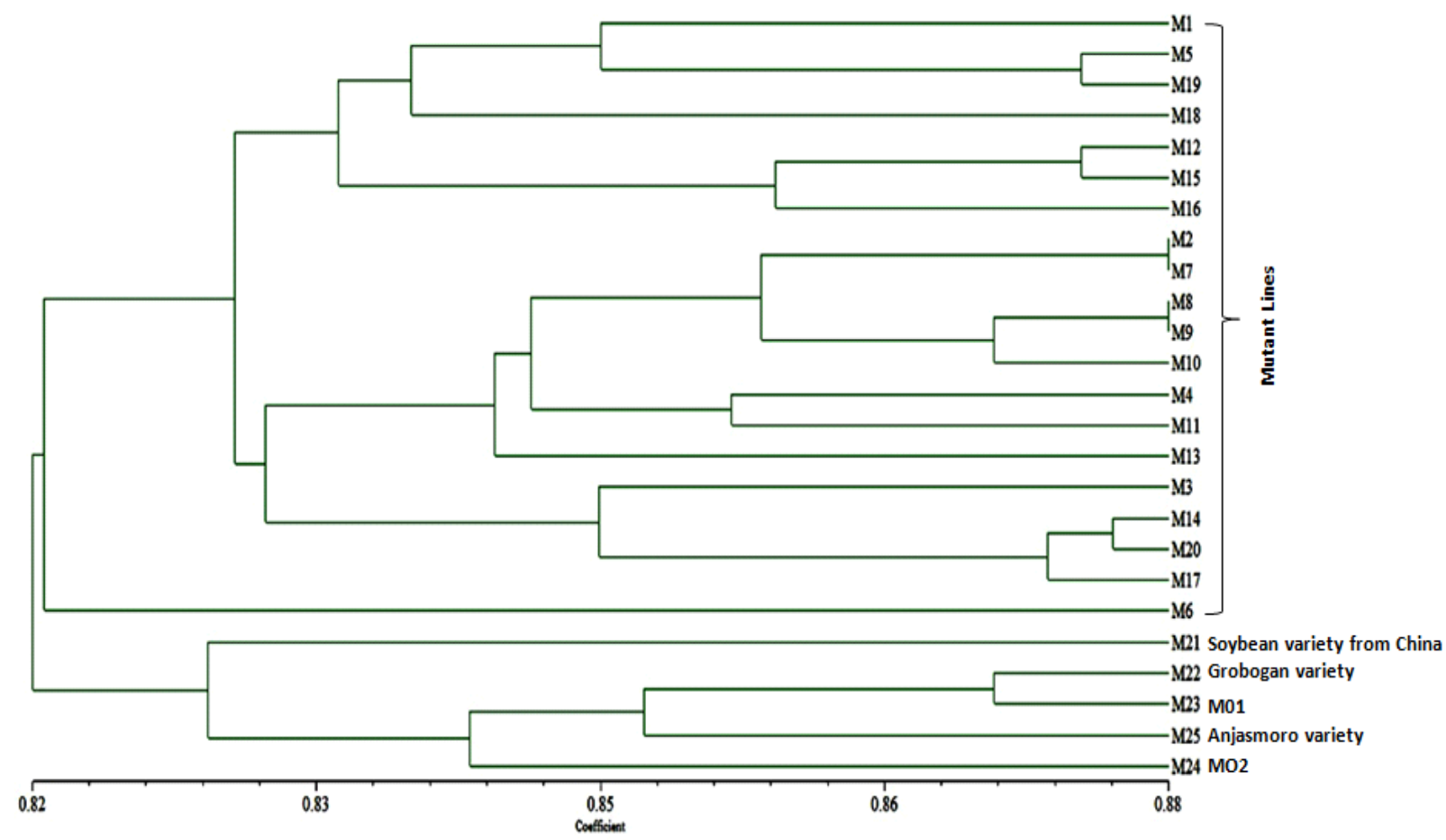

Figure 3. Phenogram of 20 soybean mutant lines in comparison with their parental lines and check varieties based on polymorphism by 14 SSR markers analyses with UPGMA. Where M1-M20: soybean mutant lines, M21: Chinese genotype (Bioed-Kc-sm-4 reg. 0500304452), M22 and M25: check varieties M23-M24: parental lines of Biosoy-M0

\section{Morpho-agronomical traits variation}

The multiple environment trials demonstrated that there was significantly different yield among promising mutant lines and their comparison with the parental lines and check varieties. Two promising lines (Biosoy-8 and Biosoy-11) revealed the higher yield in eight sites compared to other mutant lines, respectively. The two consistently were greater their yields than both check varieties and the parental lines. As indicated by the multiple folds of yields, Biosoy- 8 produced $19.1 \%, 18 \%$, and $28.7 \%$ higher than Grobogan, Anjasmoro, and BiosoyM0, respectively (Table 5). In particular, Biosoy- 8 proved its stability by producing high yield in all locations, even though there was no significant difference in 4 sites (Wonosari, Cobatok, Muara, and Pusakanagara). Both Biosoy-8 (M10) and Biosoy-11 (M17) predominantly have yielded over either parental line (Biosoy-M0), or one parent for crossing (Chinese genotype) or check varieties (Grobogan and Anjasmoro) (Table 6).

As demonstrated in this study, analysis of variance demonstrated that there were significant differences in yield characters of promising mutant lines as a result of different environments in each location (Kuningan, Muara1, Kendalpayak, and West Lombok (West Nusa Tenggara). The coefficient of variation (CV) on seven environments ranged from $13-17 \%$, indicating the experimental precision and highly homogeneity, but not in Kendalpayak. Those inconsistencies of seed yield are likely due to differential response of promising mutant lines to various growing conditions/ environments (Nath and Dasgupta 2013). This instability could also be influenced by different environmental characteristics for trial (Baye 2011). Moreover, population of silverleaf whitefly (Bemisia tabaci) and pod sucking bug (Riptortus linearis) were found quite high in Kendalpayak, especially silverleaf whitefly which was difficult to be controlled. Silverleaf whitefly could rapidly increase its populations which could reduce crop yield. Since whiteflies play a role as vectors of cowpea mild mottle virus (CMMV) on soybean plants (Tsuda et al. 2015)(Rodrigues et al. 2014), the most severe viral symptoms could be found in susceptible check variety (Anjasmoro), that had the lowest yield in Kendalpayak (Tables 5 and 6). Genetic changes due to irradiation of gamma-ray randomly clearly affected phenotypic changes including morpho-agronomic characters as demonstrated in the field trials of this study. Therefore, this study result is in good agreement with previous reports that in the case of genotype by environment interaction, the highest yield genotype in a given environment does not necessarily produce the highest yield in different environments, leading to be challenge for selection of ideal promising mutant line adaptable and stable in all environments. The genotype by environment interaction plays a major role in the performance of any mutant lines and in the success of breeding programs for the development of genetic material, adapted to various environments (Atta et al 2009; Nath and Dasgupta 2013). 
Table 5. Mean yield (ton/ha) of promising mutant lines of soybean in eight locations compared to parental line

\begin{tabular}{lcccc}
\hline Lines (code) & $\begin{array}{c}\text { Mean from } \\
\text { 8 locations } \\
\text { (ton/ha) }\end{array}$ & $\begin{array}{c}\text { Yield vs } \\
\text { Grobogan } \\
(\mathbf{\%})\end{array}$ & $\begin{array}{c}\text { Yield vs } \\
\text { Anjasmoro } \\
(\boldsymbol{\%})\end{array}$ & $\begin{array}{c}\text { Yield vs } \\
\text { Mo-Bio } \\
(\mathbf{\%})\end{array}$ \\
\hline Biosoy-1 (M2) & 2.426 & 6.5 & 5.5 & 15.1 \\
Biosoy-2 (M3) & 2.398 & 5.2 & 4.2 & 13.8 \\
Biosoy-3 (M4) & 2.563 & 12.4 & 11.4 & 21.6 \\
Biosoy-4 (M5) & 2.613 & 14.7 & 13.6 & 23.9 \\
Biosoy-5 (M6) & 2.553 & 12.0 & 11.0 & 21.1 \\
Biosoy-6 (M7) & 2.497 & 9.6 & 8.6 & 18.5 \\
Biosoy-7 (M9) & 2.528 & 10.9 & 9.9 & 19.9 \\
Biosoy-8 (M10) & 2.713 & 19.1 & 18.0 & 28.7 \\
Biosoy-9 (M13) & 2.424 & 6.4 & 5.4 & 15.0 \\
Biosoy-10(M15) & 2.622 & 15.0 & 14.0 & 24.4 \\
Biosoy-11(M17) & 2.631 & 15.5 & 14.4 & 24.8 \\
Biosoy-Mo(M24) & 2.108 & & & \\
\hline
\end{tabular}

Based on the yield in multiple environments supported by other morphological characters, two lines (Biosoy- 8 and Biosoy-11) could be promising lines. The number of pods of Biosoy- 8 and Biosoy-11 was higher than un-irradiated (Biosoy-M0) line and Grobogan, but less than Anjasmoro. While the number of branches of both promising mutant lines (Biosoy-8 and Biosoy-11) was higher than Grobogan but equal to Anjasmoro. Although the number of pods and branches of Biosoy- 8 and Biosoy-11 were less than those in Anjasmoro, these seeds size was larger than Anjasmoro. The seed size (reflected 100 seed weight) of the Biosoy- 8 and Biosoy-11 was larger (22 g/100 seeds) than Anjasmoro (15 g/100 seeds) (Table 7). Compared to Grobogan, seeds size of Biosoy- 8 and Biosoy-11 were slightly large. Grobogan seed weight was $21 \mathrm{~g} / 100$ seeds, while Biosoy- 8 and Biosoy-11 were $22 \mathrm{~g} / 100$ seeds. This finding suggested that there was differential adaptation of soybean line. In line with study from Tukamuhabwa et al. (2012), based on several locations tests in Uganda, two categories of soybean were found to be widely adapted genotypes and genotypes adapted to an optimal environment. Similarly, Rasyad and Idwar (2010) identified soybean genotypes with widely adaptation and specific locations based on soybean seed yield. However, these study results were in contrast to field trials of soybean in multiple environments reported by Aremu et al. (2007) as a result of unstable soybean genotype. Thus, a plant genotype is considered stable when the ability of this genotype has the same response in different environmental conditions. The regression coefficient of the character to environment index is equal to one (1) and the regression deviation does not differ from zero.

The $\mathrm{G} \times \mathrm{E}$ interaction found in this multi-environment trials in our study was relevant to previous studies as a common phenomenon in plant breeding activities (Rasyad and Idwar 2010; Crossa 2012). G×E indicated qualitative interaction and become a major factor in supporting the recommendation of genotype selection (Gauch et al. 2008; Karimizadeh et al. 2013; Stagnari et al. 2013). Therefore, analysis of combined variance of the eight field environmental was done and showed that the three parameters, such as environment, genotype, and genotype by environment interactions significantly affected the seed yield of the promising mutant lines of soybean (Table 7). The varied altitude, soil type, and seasons/climate across 8 location trials resulted in different seed yields of each promising mutants. The significant interaction between promising mutant lines and environment showed that promising mutant lines of soybean have ability to adapt in various environments or specific locations/environments (Table 8).

Table 6. Seed yield (ton/ha) of 11 soybean promising mutant lines and four check varieties tested in eight locations

\begin{tabular}{|c|c|c|c|c|c|c|c|c|c|}
\hline \multirow{2}{*}{ Lines (code) } & \multicolumn{8}{|c|}{ Yield (t/h) } & \multirow{2}{*}{ Mean } \\
\hline & Wonosari & Cibatok & kuningan & Muara & Muara 1 & Kendalpyk & NTB & Psk nagara & \\
\hline Biosoy-1 (M2) & $1.971 \mathrm{a}$ & $2.739 \mathrm{a}$ & $2.535 \mathrm{abc}$ & $2.370 \mathrm{a}$ & $3.378 \mathrm{bc}$ & $1.379 \mathrm{bcd}$ & $2.640 \mathrm{bc}$ & $2.397 \mathrm{a}$ & 2.426 \\
\hline Biosoy-2 (M3) & $2.067 \mathrm{a}$ & $2.528 \mathrm{a}$ & $3.215 \mathrm{~cd}$ & $2.427 \mathrm{a}$ & $2.677 \mathrm{~b}$ & $1.254 \mathrm{abc}$ & $2.398 \mathrm{bc}$ & $2.620 \mathrm{a}$ & 2.398 \\
\hline Biosoy-3 (M4) & $2.073 \mathrm{a}$ & $2.607 \mathrm{a}$ & $3.613 \mathrm{~d}$ & $2.414 \mathrm{a}$ & 2.724 b & $1.848 \mathrm{~d}$ & $2.619 b c$ & $2.602 \mathrm{a}$ & 2.563 \\
\hline Biosoy-4 (M5) & $1.870 \mathrm{a}$ & $2.810 \mathrm{a}$ & $2.942 \mathrm{bcd}$ & $2.194 \mathrm{a}$ & $3.281 \mathrm{bc}$ & $1.790 \mathrm{~d}$ & $2.705 \mathrm{bc}$ & $3.310 \mathrm{a}$ & 2.613 \\
\hline Biosoy-5 (M6) & $2.302 \mathrm{a}$ & $2.314 \mathrm{a}$ & $2.594 a b c$ & $2.596 \mathrm{a}$ & $3.564 \mathrm{c}$ & $1.541 \mathrm{abc}$ & $2.806 \mathrm{bc}$ & $2.708 \mathrm{a}$ & 2.553 \\
\hline Biosoy-6 (M7) & $2.050 \mathrm{a}$ & $2.397 \mathrm{a}$ & $2.967 \mathrm{bcd}$ & $2.333 \mathrm{a}$ & $3.241 \mathrm{bc}$ & $1.624 \mathrm{~cd}$ & $2.666 \mathrm{bc}$ & $2.701 \mathrm{a}$ & 2.497 \\
\hline Biosoy-7 (M9) & $2.460 \mathrm{a}$ & $2.544 \mathrm{a}$ & $2.974 \mathrm{bcd}$ & $2.357 \mathrm{a}$ & $3.400 \mathrm{bc}$ & $1.486 \mathrm{bcd}$ & $2.233 \mathrm{~b}$ & $2.773 \mathrm{a}$ & 2.528 \\
\hline Biosoy-8 (M10) & $2.269 \mathrm{a}$ & $2.710 \mathrm{a}$ & $3.289 \mathrm{~cd}$ & $2.886 \mathrm{a}$ & $3.124 \mathrm{bc}$ & $1.700 \mathrm{~cd}$ & $2.864 \mathrm{c}$ & $2.866 \mathrm{a}$ & 2.713 \\
\hline Biosoy-9 (M13) & $2.257 \mathrm{a}$ & $2.329 \mathrm{a}$ & $2.388 \mathrm{abc}$ & $2.626 \mathrm{a}$ & $2.852 \mathrm{bc}$ & $1.495 \mathrm{bcd}$ & $2.881 \mathrm{c}$ & $2.568 \mathrm{a}$ & 2.424 \\
\hline Biosoy-10 (M15) & $2.511 \mathrm{a}$ & $2.659 \mathrm{a}$ & $3.577 \mathrm{~d}$ & $2.317 \mathrm{a}$ & $3.092 \mathrm{bc}$ & $1.785 \mathrm{~d}$ & $2.434 \mathrm{bc}$ & $2.600 \mathrm{a}$ & 2.622 \\
\hline Biosoy-11 (M17) & $2.131 \mathrm{a}$ & $2.626 \mathrm{a}$ & $3.125 \mathrm{bcd}$ & $2.686 \mathrm{a}$ & $3.551 \mathrm{c}$ & $1.670 \mathrm{~cd}$ & $2.988 \mathrm{c}$ & $2.274 \mathrm{a}$ & 2.631 \\
\hline Biosoy Mo (M24) & $2.206 \mathrm{a}$ & $2.149 \mathrm{a}$ & $2.494 \mathrm{abc}$ & $2.705 \mathrm{a}$ & $1.837 \mathrm{a}$ & $0.895 \mathrm{a}$ & $1.636 \mathrm{a}$ & $2.940 \mathrm{a}$ & 2.108 \\
\hline Chinese genotype (M21) & $2.326 \mathrm{a}$ & $2.780 \mathrm{a}$ & $2.250 \mathrm{ab}$ & $2.579 \mathrm{a}$ & $1.948 \mathrm{a}$ & $0.812 \mathrm{a}$ & $1.522 \mathrm{a}$ & $2.094 \mathrm{a}$ & 2.029 \\
\hline Grobogan (M22) & $2.169 \mathrm{a}$ & $2.191 \mathrm{a}$ & $1.958 \mathrm{a}$ & $2.952 \mathrm{a}$ & $3.388 \mathrm{bc}$ & $1.095 \mathrm{ab}$ & $1.632 \mathrm{a}$ & $2.847 \mathrm{a}$ & 2.279 \\
\hline Anjasmoro (M25) & $2.079 \mathrm{a}$ & $2.696 \mathrm{a}$ & $2.207 \mathrm{ab}$ & $2.441 \mathrm{a}$ & $2.920 \mathrm{bc}$ & $0.810 \mathrm{a}$ & $2.413 \mathrm{bc}$ & $2.839 \mathrm{a}$ & 2.301 \\
\hline $\mathrm{CV}(\%)$ & 11.760 & 12.026 & 16.730 & $11.731 \%$ & 12.646 & 17.811 & 13.366 & 16.436 & \\
\hline
\end{tabular}

Note: The numbers in the same column followed by the same letters were not significantly different from each other at $5 \%$ according to DMRT test 
Table 7. Agronomic and yield characters of promising mutant lines evaluated across eight locations

\begin{tabular}{|c|c|c|c|c|c|c|c|c|}
\hline \multirow{2}{*}{ Lines (code) } & \multicolumn{8}{|c|}{ Agronomic and yield characters } \\
\hline & DF & DM & PH & NP & NFN & NB & $100 \mathrm{SW}$ & Yield \\
\hline Biosoy-1(M2) & 33 & 83 & 42.3 & 33 & 10 & 3 & 20 & 2.426 \\
\hline Biosoy-2(M3) & 33 & 83 & 37.0 & 34 & 10 & 3 & 21 & 2.398 \\
\hline Biosoy-3(M4) & 34 & 84 & 40.5 & 34 & 10 & 3 & 21 & 2.563 \\
\hline Biosoy-4(M5) & 34 & 84 & 39.0 & 37 & 11 & 4 & 21 & 2.613 \\
\hline Biosoy-5(M6) & 33 & 83 & 37.9 & 32 & 10 & 3 & 21 & 2.553 \\
\hline Biosoy-6(M7) & 33 & 84 & 38.0 & 35 & 10 & 3 & 21 & 2.497 \\
\hline Biosoy-7(M9) & 34 & 84 & 37.7 & 35 & 10 & 3 & 21 & 2.528 \\
\hline Biosoy-8(M10) & 33 & 83 & 37.0 & 33 & 10 & 3 & 22 & 2.713 \\
\hline Biosoy-9(M13) & 33 & 82 & 42.1 & 31 & 10 & 3 & 21 & 2.424 \\
\hline Biosoy-10(M15) & 33 & 83 & 40.1 & 32 & 10 & 3 & 22 & 2.622 \\
\hline Biosoy-11(M17) & 33 & 84 & 37.3 & 35 & 10 & 3 & 22 & 2.631 \\
\hline Mo-Biosoy (M24) & 32 & 77 & 48.7 & 29 & 7 & 2 & 21 & 2.108 \\
\hline Chinese genotype(M21) & 33 & 83 & 37.7 & 23 & 7 & 2 & 34 & 2.029 \\
\hline Grobogan (M22) & 31 & 76 & 47.7 & 29 & 9 & 2 & 21 & 2.279 \\
\hline Anjasmoro (M25) & 37 & 87 & 67.2 & 41 & 10 & 3 & 16 & 2.301 \\
\hline
\end{tabular}

Note: DF: days to flowering (day). DM: days to maturity (day). PH: plant height (cm). NP: number of pods. NFN: Number of fertile nodes. NB: number of branches. $100 \mathrm{SW}: 100$ seed weight (g). SY: seed yield (ton/ha)

Table 8. Combined analysis of variance on seed yield of 11 soybean promising mutant lines and four check varieties tested in eight environments

\begin{tabular}{lrrrrr}
\hline $\begin{array}{c}\text { Source of } \\
\text { variation }\end{array}$ & dF & \multicolumn{1}{c}{ SS } & MS & F & P \\
\hline Environments (E) & 7 & 73.6776 & 10.5254 & 85.93 & 0.000 \\
Replication & 16 & 9.6721 & 0.6045 & 4.94 & 0.000 \\
Genotypes (G) & 14 & 12.7395 & 0.9100 & 7.43 & 0.000 \\
G×E & 98 & 33.2936 & 0.3397 & 2.77 & 0.000 \\
Error & 223 & 27.3137 & 0.1225 & & \\
Total & 358 & & & &
\end{tabular}

Note: dF: degree of freedom. SS: sum of squares. MS: mean squares. Fl: F ratio, P: P value

The degree of interaction of promising lines with these environments is important to determine suitable areas for their adaptation to cope with a particular environment. Moreover, environmental factors assessment on the genetic potential for a promising mutant line could direct a clue on their adaptability and stability (Oladose et al. 2016). Therefore, a case of significant interaction between mutant lines and environment would need further tests to ensure their stability to adaptation on given environment. In relevant with previous reports (Tukamuhabwa et al. 2012; Nath and Dasgupta 2013), significant G×E interaction analysis could identify the superiority of each line exhibited predominant morpho-agronomical characters in corresponding environment as a prerequisite of genotype stability, indicating as the key for breeding.

Stability analysis of 11 promising mutant lines of soybean (Table 9), indicated that all promising mutant lines
(Biosoy-1, Biosoy-2, Biosoy-3, Biosoy-4, Biosoy-5, Biosoy-6, Biosoy-7, Biosoy-8, Biosoy-9, Biosoy-10, and Biosoy-11) and Anjasmoro (lower yield) as check varieties were stable, in contrast to the other check varieties (Grobogan and Biosoy-M0). In eight environments, Biosoy- 8 had the highest seed yield (2.713 ton/ha) followed by Biosoy-11 (2.631 ton/ha). Biosoy-8 and Biosoy-11, which have yield potential of 3.12 and 3.3 ton/ha, respectively, indicating $16-20 \%$ higher than Grobogan or $10-16 \%$ against Anjasmoro. While some lines (Biosoy-3, Biosoy-4, Biosoy-5, and Biosoy-10) produced yield above 2.5 ton/ha (Table 4), indicating their higher production than national production per ha. Based on the yield stability in various environments supported by agronomic characters (number of pods and seeds yield), two promising mutant lines (Biosoy- 8 and Biosoy-11) had a high considerable opportunity to be released as improved high yielding soybean varieties with large seeds. These promising soybean mutant lines resulted in this study are in good agreement with previous reports to prove the strength of gamma irradiation to produce new plant varieties (Asare et al. 2017; Harsanti and Yulidar 2019). The study clearly demonstrated that the agronomical traits evaluation and molecular variation of promising mutant lines could assist their identification and maximal utilization in the future. Various lines can be obtained from crosses between two diverse parental lines and mutation on advanced generation accompanied by selection will be beneficial tool for genetic improvement (Acquaah 2007). Another breeding approach might also contribute to select diverse mutants lines (especially for traits which are quantitatively inherited) as parental genotypes to generate desirable varieties. 
Table 9. Stability test of the tested lines

\begin{tabular}{lccrcccccc}
\hline Lines(code) & Average & $\mathbf{B}$ & t-calc & t table & $\mathbf{b = 1}$ & F-calc & F table & SD = 0 & Conclusion \\
\hline Biosoy-1(M2)) & 2.426 & 1.085 & 0.403 & 2.447 & Accepted & 0.638 & 2.193 & Accepted & Stable \\
Biosoy-2(M3) & 2.398 & 1.087 & 0.506 & 2.447 & Accepted & 0.425 & 2.193 & Accepted & Stable \\
Biosoy-3(M4) & 2.563 & 0.815 & -0.643 & 2.447 & Accepted & 1.199 & 2.193 & Accepted & Stable \\
Biosoy-4(M5 & 2.613 & 1.022 & 0.077 & 2.447 & Accepted & 1.138 & 2.193 & Accepted & Stable \\
Biosoy-5(M6) & 2.553 & 1.034 & 0.151 & 2.447 & Accepted & 0.733 & 2.193 & Accepted & Stable \\
Biosoy-6(M7) & 2.497 & 0.988 & -0.076 & 2.447 & Accepted & 0.350 & 2.193 & Accepted & Stable \\
Biosoy-7(M9) & 2.528 & 1.088 & 0.524 & 2.447 & Accepted & 0.411 & 2.193 & Accepted & Stable \\
Biosoy-8(M10) & 2.713 & 1.003 & 0.021 & 2.447 & Accepted & 0.221 & 2.193 & Accepted & Stable \\
Biosoy-9(M13) & 2.424 & 0.767 & -1.176 & 2.447 & Accepted & 0.567 & 2.193 & Accepted & Stable \\
Biosoy-10(M15) & 2.622 & 0.900 & -0.391 & 2.447 & Accepted & 0.947 & 2.193 & Accepted & Stable \\
Biosoy-11(M17) & 2.631 & 1.052 & 0.195 & 2.447 & Accepted & 1.030 & 2.193 & Accepted & Stable \\
Mo-Biosoy (M24) & 2.108 & 0.894 & -0.258 & 2.447 & Accepted & 2.431 & 2.193 & Rejected & Unstable \\
Chinese genotype (M21) & 2.039 & 0.823 & -0.434 & 2.447 & Accepted & 2.398 & 2.193 & Rejected & Unstable \\
Grobogan (M22) & 2.279 & 1.179 & 0.434 & 2.447 & Accepted & 2.441 & 2.193 & Rejected & Unstable \\
Anjasmoro (M25) & 2.301 & 1.264 & 1.156 & 2.447 & Accepted & 0.755 & 2.193 & Accepted & Stable \\
\hline Nias Regled
\end{tabular}

Note: Regression coefficient $\mathrm{b}$ and $\mathrm{H}_{0}: \mathrm{b}=1$ and $\mathrm{H}_{0}$ test: $\mathrm{SD}=0$ )*.* Sources: Eberhart and Russell (1966)

In conclusion, the adaptation tests in several locations with different environments which was supported by data on resistance to rust, sucker pests, and pod borer revealed two soybean promising lines, namely Ped-MB-2-896-1 (Biosoy-8) and Ped-MB-5-10 (Biosoy-11) that have superiorities over check varieties Grobogan and Anjasmoro. Ped-MB-2-896-1 line has a potential yield of $3.29 \mathrm{ton} / \mathrm{ha}$ with an average yield of $2.71 \mathrm{ton} / \mathrm{ha}$, which is $19.1 \%$ higher than Grobogan and $18.0 \%$ higher than Anjasmoro, medium age (83 days) with 33 pods/plant, large seed (22.2 g/100 seeds), sturdy and wide stem with a diameter of $7.9 \mathrm{~mm}$, resistant to leaf rust disease, resistant to pests pod suckers and pod borer, with DNA fingerprint profile of TACAAGGGCA. Bulk-M-B-5-10 line could be described that its potential yield is of 3.55 ton/ha with an average yield of 2.63 ton/ha, which is $15.5 \%$ higher than Grobogan and $14.4 \%$ higher than Anjasmoro, medium age (84 days), having 35 pods/plant and large seed $(22.4 \mathrm{~g} / 100$ seeds), sturdy and wide stem with a diameter of $7.6 \mathrm{~mm}$, resistant to leaf rust, moderate resistant to leaf sucker pest and pod borer resistance, with DNA fingerprint profile of AGCATGTGTA. Both lines have stable yields at various locations. Genetic diversity among mutant lines generated from advanced cross and in comparison with the parent was indicative of existed mutation due to gamma-ray which reflected to agronomical changes. Therefore, Ped-MB-2896-1 (Biosoy-8) and Ped-MB-5-10 (Biosoy-11) which had advantages over check varieties Grobogan and Anjasmoro had been successfully selected and were released as newly improved soybean varieties named with Biosoy-1 and Biosoy-2, respectively, in 2018 in Indonesia. Notably that this gamma irradiation proved an adept means of encouraging to produce new genetic variation (Singh and Datta 2010; Pushparajan et al. 2014). The combination of hybridization and induce mutation inbreeding has been successfully used in this study to generate new soybean varieties with desirable morpho-agronomical characters.

\section{ACKNOWLEDGEMENTS}

The authors gratefully thank to Ratna Utari, Jumanta, Pardjo for high dedication to work in field on multiple locations trials in Java province, Meddy Saputra and Nazhirotul Ilmiyah for valuable technical assistance in molecular work and prior data analysis. This work was funded by APBN-routine budget year 2015-2016 from the ICABIOGRAD program under the Indonesian Agency for Agricultural Research and Development, Ministry of Agriculture, Republic of Indonesia.

\section{REFERENCES}

Acquaah G. 2007. Principles of Plant Genetics and Breeding. Blackwell Publishing, New York, USA. DOI: 10.1002/9781118313718

Ahloowalia B, Maluszynski M, Nichterlein K. 2004. Global Impact of mutation derived varieties. Euphytica 135: 187-204. DOI: $10.1023 / \mathrm{b}$ : euph.0000014914.85465.4f

Arefrad M, Nematzadeh G, Jelodar NB, Kazemitabar SK. 2012. Improvement of qualitative and quantitative traits in soybean (Glycine $\max ($ L.) Merrill) through gamma irradiation. Plant Mol Breed 1: 1015 .

Aremu CO, Adebayo TA, Oyekunle M, Ariyo OJ. 2007. The relative discriminatory ability of techniques measuring genotype $\mathrm{x}$ environmental interaction in soybean in semi-arid and rain=forest environments of Nigeria. Agric J 2: 210-215.

Asadi, Soemartono, Woerjono M, Harjosudarmo J. 2004. Keefektifan metode seleksi modifikasi bulk dan pedigri untuk karakter agronomi, ketahanan terhadap virus kerdil (SSV) galur-galur F7 kedelai. Zuriat 5: 64-76. [Indonesian]

Asare AT, Mensah F, Acheampong S, Asare-Bediako E, Armah J. 2017. Effect of gamma irradiation on agromorphological characteristics of okra (Abelmoschus esculentus L. Moench.). Adv Agric 2017: 2385106. DOI: $10.1155 / 2017 / 2385106$

Atta B, Shah TM, Abbas G, Haq MA.2009. Genotype X environment interaction for seed yield in Kabul chickpea (Cicer arietinum L. genotypes developed through mutation breeding. Pak J Bot 41: 18831890

BPS (Badan Pusat Statistik). 2019. https: //www.bps.go.id

Baye TM, Abebe T, Wilke RA. 2011. Genotype-environment interactions and their translational implications. J Pers Med 8: 59-70. DOI: $10.2217 /$ pme. 10.75 
Borevitz JO, Liang D, Plouffe D, Chang HS, Zhu T, Weigel D, Berry CC, Winzeler E, Chory J. 2003. Large-scale identification of singlefeature polymorphisms in complex genomes. Genome Res 13: 513523. DOI: $10.1101 / \mathrm{gr} .541303$

Carsono N. 2008. Peran pemuliaan tanaman dalam meningatkan produksi pertanian di Indonesia. Seminar on Agricultural Sciences. Universitas Padjadjaran, Sumedang. [Indonesian]

Choudhary N, Ahuja U, Chawla V, Jain RK, Kumari P, Batan KR 2011. Morphological and molecular variability in weedy rice of Haryana. Asian J Agric Res 5: 250-259.

Crossa J. 2012. From genotypexenvironment interaction to genexenvironment interaction. Curr Genom 13: 225-244. DOI: $10.2174 / 138920212800543066$

Dhanavel D, Gnanamurthy S, Girija M. 2012. Effect of gamma rays on induced chromosomal variation in cowpea Vigna unguiculata (L) Walp. Int J Curr Sci Spec Issue: 245-250. DOI: 10.18052/www.scipress.com/ilns.22.33

Doyle JJ, Doyle JL. 1990. Isolation of plant DNA from fresh tissue. Focus 12: 13-15.

Eberhart SA, Russel WA. 1966. Stability parameters for comparing

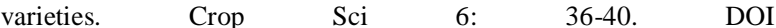
10.2135/cropsci1966.0011183x000600010011x

Gauch HG, Piepho HP, Annicchiarico P. 2008. Statistical analysis of yield trials by AMMI and GGE: Further considerations. Crop Sci 48: 866889. DOI: $10.2135 /$ cropsci2007.09.0513

Girija M, Dhanavel D, Gnanamurthy S. 2013. Gamma rays and EMS induced flower color and seed mutants in cowpea (Vigna unguiculata L. Walp). Adv Appl Sci Res 4: 134-139.

Gobinath P, Pavadai P. 2015. Effect of gamma rays on morphology, growth, yield and biochemical analysis in soybean (Glycine max (L.) Merr.). World Sci News 23: 1-12

Gomez KA, Gomez AA. 1984. Statistical Procedures for Agricultural Research. 2nd ed. John Wiley \& Sons, New York.

Hamzekhanlu MY, Darbandi AI, Beiranvand NP, Hallajian MT, Majdabadi A. 2011. Phenotypic and molecular analysis of M7 generation of soybean mutant lines through random amplified polymorphic DNA (RAPD) marker and some morphological traits. Afr J Agric Res 6: 1779-1785. DOI: 10.5897/AJAR10.1109

Hanafiah DS, Trikoesoemaningtyas, Sudirman Y, Desta W. 2010. Induced mutations by gamma ray irradiation to Argomulyo soybean. Nusantara Biosci 2: 121-125. DOI: 10.13057/nusbiosci/n020303

Harsanti L, Yulidar. 2019. Soybean variety growth (Glycine max (L.) Merril) on M2 generation with mutation techniques. Indon J Nuc Sci Tech. DOI: 10.17146/jstni.2019.1.1.4104

Herrera G, Dunia PD, Iris PA, Gelis TN, Alejandro P, Cesar PM, Joe MT 2008. Assessment of genetic diversity in Venezuelan rice cultivars using simple sequence repeats markers. Biotechnology 11: 5-7. DOI: 10.2225/vol11-issue5-fulltext-6

Karimizadeh R, Mohammadi M, Sabaghni N, Mahmoodi AA, Roustami B, Seyyedi F, Akbari F. 2013. GGE biplot analysis of yield stability in multi-environment trials of lentil genotypes under rainfed condition. Not Sci Biol 5: 256-262. DOI: 10.15835/nsb529067

Karthika R, Lakshmi BS. 2006. Effect of gamma rays and EMS on two varieties of soybean. Asian J Plant Sci 5: 721-724.

Kumar A, Bassi FM, Jimenez MKM, Ghavami F, Mazaheri M, Simons K, Iqbal MJ, Mergoum M, Kianian SF, Kianian PMA. 2014. Radiation hybrids: a valuable tool for genetic, genomic and functional analysis of plant genomes. In: Genomics of Plant Genetic Resources: Volume 1. Managing, Sequencing and Mining Genetic Resources, Springer, Netherlands. DOI: 10.1007/978-94-007-7572-5_12.

Lenis JM, Gillman JD, Lee JD, Shannon SG, Bilyeu KD. 2010. Soybean seed lipoxygenase genes: molecular characterization and development of molecular marker assays. Theor Appl Genet 120: 1139-1149. DOI: $10.1007 / \mathrm{s} 00122-009-1241-9$

Lestari P, Risliawati A, Utami DW, Hidayatun N, Santosa TJ, Chaerani. 2016. Development of SSR-based specific identity on 29 Indonesia local soybean varieties. J Biol Indon 12: 219-229.

Lee KJ, Hwang JE, Velusamy V, Ha BK, Kim JB, Kim SH, Ahn JW, Kang SY, Kim DS. 2014. Selection and molecular characterization of a lipoxygenase-free soybean mutant line induced by gamma irradiation. Theor Appl Genet 124: 2405-2413. DOI: 10.1007/s00122014-2385-9.

Liu K, Muse SV. 2005. PowerMarker: An integrated analysis environment for genetic marker analysis. Bioinformatics 21: 2128-2129. DOI: 10.1093/bioinformatics/bti282
Malek MA, Rafii MY, Afroz MSS, Nath UK, Mondal MMA. 2014. Morphological characterization and assessment of genetic variability, character association, and divergence in soybean mutants. Sci World J 2014: 968796. DOI: 10.1155/2014/968796

Mejri S, Mabrouk Y, Voisin M, Delavault p, Simier P, Saidi M, Belhadj O. 2012. Variation in quantitative characters of faba bean after seed irradiation and associated molecular changes. Afr J Biotech 11: 83838390.

Meliala JHS, Basuki N, Sugianto A. 2016. Pengaruh iradiasi sinar gamma terhadap perubahan fenotipik tanaman padi gogo (Oryza sativa L.). Produksi Tanaman 4: 585-594. [Indonesian]

Ministry of Agriculture. 2016. Outlook: agriculture commodity food crops sub-sector. Data Center and Information System Agriculture. Ministry of Agriculture, Jakarta, Indonesia.

Muduli KC, Misra RC. 2007. Efficacy of mutagenic treatments in producing useful mutants in finger millet (Eleusine coracana) Gaertn. Indian J Genet Pl Br 67: 232-237.

Mudibu J, Nkongolo KKC, Kalonji-Mbuyi A, Kizungu RV. 2012. Effect of gamma irradiation on morpho-agronomic characteristics of soybeans (Glycine $\max$ L.). Am J Plant Sci 3: 331-337. DOI: 10.4236/ajps.2012.33039

Nath D, Dasgupta T. 2013. Genotypexenvironment interaction and stability analysis in mungbean. IOASR-JAVS 5: 62-70. DOI: 10.9790/2380-0516270.

Nei M, Li W-H. 1979. Mathematical model for studying genetic variation in terms of restriction endonuclease. Proc Natl Acad Sci USA 76: 5269-5273

Oladose Y, Rafi MY, Abdullah N, Hussin G, Ramli A, Rahim HA, Miah G, Usman M. 2016. Principle and application of plant mutagenesis in crop improvement: a review. Biotechnol Biotec Eq 30: 1-16. DOI: $10.1080 / 13102818.2015 .1087333$

Pavadai P, Girija M, Dhanavel D. 2010. Effect of gamma rays on some yield parameters and protein content of soybean in M2, M3 and M4 generations. J Exp Sci 1: 8-11.

Pushparajan G, Sanoopand S, Harinarayanan MK. 2014. Effect of gamma rays on yield attributing characters of Okra [Abelmoschus esculentus (L.) Moench]. Intl J Adv Res 2: 535-540.

Rasyad A, Idwar. 2010. Genotype x environment interaction of yield components and stability of several soybean genotypes in Riau Province. J Agron Indon 38 (1): 25-29. [Indonesian]

Rodrigues JCV, Kondidie DB, Estevez-Jensen C, Kitajima, EW, Huckaba RM, Foster JE. 2014. Infection in soybean and on multiple host plants in Puerto Rico by an isolate of cowpea mild mottle virus. Virus Rev Res 19: 1-4. DOI: 10.17525/vrr.v19i1.101.

Rohlf FJ. 2000. Statistical power comparisons among alternative morphometric methods. Amer J Phys Anthropol 111: 463-478.

SAS. 2002. Static Analysis: $9^{\text {th }}$ International Symposium. Springer. Germany.

Sangsiri C, Worawit S, Peerasak S. 2005. Gamma radiation-induced mutations in mungbean. Sci Asia 31: 251-255. DOI: 10.2306/scienceasia1513-1874.2005.31.251

Singh B, Datta PS. 2010. Effect of low dose gamma irradiation on plant and grain nutrition of wheat. Radiat Phys Chem 79: 819-825. DOI: 10.1016/radphyschem.2010.03.011

Soeranto H. 2011. Plant Breeding with Mutation Technique. Indonesian Center for Isotopes and Radiation Technology Research and Development. National Nuclear Energy Agency of Indonesia, Jakarta. [Indonesian]

Sonia M, Yassine M, Marie V, Philippe D, Philippe S, Mouldi S, Omrane B. 2012. Variation in quantitative characters of faba bean after seed irradiation and associated molecular changes. Afr J Agric Res11: 8383-8390. DOI: $10.5897 /$ ajb11.291

Stagnari F, Onofri A, Codianni P, Pisante M. 2013. Durum wheat varieties in $\mathrm{N}$-deficient environments and organic farming: a comparison of yield, quality and stability performances. Plant Breed 132: 266-275. DOI: $10.1111 /$ pbr.12044

Tembo L, Munyinda K. 2015. Clustering common bean mutants based on heterotic grouping. Afr Crop Sci23 (1): 1-7.

Togatorop ER, Aisyah SI, Damanik MRM. 2016. Effect of physical mutation by gamma ray Irradiation on genetic variability and performance of Coleus blumei. J Hort Indonesia 7: 187-194.

Tsuda M, Kaga A, Anai T, Shimizu T, Sayama T, Takagi K, Machita K, Watanabe S, Nishimura M, Yamada N, Mori S, Sasaki H, Kanamori H, Katayose Y, Ishimoto M. 2015. Construction of a high-density mutant library in soybean and development of a mutant retrieval method using amplicon sequencing. BMC Genomics 16: 1014. 
Tukamuhabwa P, Asiimwe M, Nabasirye M, Kabayi P, Maphosa M 2012. Genotype by environment interaction of advanced generation soybean lines for grain yield in Uganda. Afr Crop Sci20: 107-115.

Warid, Khumaida N, Purwito A, Syukur M. 2017. Effect of gamma-ray irradiation on the first generation (M1) to obtain new superior genotypes of drought-tolerant soybeans. Agrotrop 7: 11-21.
Widiarsih S, Dwimahyani I. 2013. Aplikasi iradiasi gamma untuk pemuliaan mutasi anggrek bulan (Phalaenopsis amabilis B1). Aplikasi Isotop dan Radiasi 9: 59-66. [Indonesian]

Yuliasti, Reflinur. 2017. Field performance of five soybean mutants under drought stress conditions and molecular analysis using SSR markers. Atom Indonesia 43 (2): 103-109. DOI: 10.17146/aij.2017.685. 